\title{
The role of chromosome abnormalities in reproductive failure
}

\author{
PA Jacobs
}

Wessex Regional Cytogenetics Unit, General Hospital, Salisbury, Wiltshire, UK

(28 Réunion de la Société Française pour l'Étude de la Fertilité; Paris, 19-21 octobre 1989)

\begin{abstract}
Summary - The frequency of chromosome abnormalities in spontaneous abortions, stillbirths, livebirths and among all clinically recognized pregnancies is given. Data on the parental origin of sex chromosome abnormalities and certain autosomal trisomies determined using molecular probes are presented and the proportion of sperm and eggs that are nullisomic or disomic for a sex chromosome or an autosome 16,18 or 21 is calculated.
\end{abstract}

chromosome / abnormalities / reproduction / gametes

Résumé - Le rôle des anomalies chromosomiques dans les échecs de la reproduction. Dans l'espèce humaine, ce sont les anomalies chromosomiques qui représentent la cause la plus fréquente de mort fotale. De toutes les grossesses qui évoluent au-delà de la $8^{\theta}$ semaine puis avortent spontanément, environ $50 \%$ sont chromosomiquement anormales alors que $5 \%$ de celles donnant naissance à des foetus mort-nés entre 28 semaines et l'accouchement sont anormales chromosomiquement. En revanche, des anomalies chromosomiques sont relevées dans seulement $0,5 \%$ des nouveau-nés vivants.

La majorité des anomalies chromosomiques résultent d'erreurs se produisant au cours de la gamétogénèse chez des parents chromosomiquement normaux bien qu'une faible proportion soit la conséquence d'une erreur au moment de la fécondation ou lors de la division cellulaire précoce d'un zygote chromosomiquement normal. Par conséquent, la grande majorité des anomalies chromosomiques peuvent être directement attribuées au spermatozoïde ou à l'ovocyte qui ont une constitution chromosomique anormale conséquente à une erreur se produisant lors de la première ou de la seconde division méiotique chez l'un ou l'autre parent.

L'origine de ces erreurs, se produisant dans des gametes chromosomiquement anormaux, peut être étudiée en comparant les marqueurs génétiques chez les parents et chez le conceptus chromosomiquement anormal. Jusqu'à une période relativement récente les seuls marqueurs génétiques utiles, qui étaient disponibles, étaient le polymorphisme chromosomique et les caractéristiques biochimiques exprimées dans les cellules en culture. Cependant, les récents développements des sondes d'ADN ont permis de déterminer l'origine parentale de presque toutes les anomalies chromosomiques et, dans certains cas, de comprendre la nature de l'erreur induisant un conceptus anormal.

chromosomes / anomalies / reproduction / gamètes 


\section{INTRODUCTION}

Man appears to be unique among mammals with respect to the very high level of reproductive wastage that is present at all stages of pregnancy. The fecundity of man has been estimated to be around $25 \%$ and there is little evidence that this has changed in any significant way over the past $\mathbf{2 0 0}$ years, the only period for which records are available (Short, 1979). It appears that at least $25 \%$ of all conceptuses are lost prior to implantation (Kline and Stein, 1985), a further $30 \%$ in the early post-implantation period prior to the pregnancy being clinically recognizable, while at least $15 \%$ are spontaneously aborted between the 6th and 28th weeks of pregnancy, and $1 \%$ are stillborn in. the later stages of pregnancy.

The reasons for pregnancy wastage in the pre-implantation and early postimplantation periods are unknown because these stages of pregnancy are difficult to study. However, it seems reasonable to suppose that many early losses are attributable to cytogenetic abnormalities that are incompatible with survival of the conceptus to the stage where it is clinically recognizable. Indeed, there is evidence from the study of mice with segre- gating robertsonian translocations that all monosomics and many trisomics are lethal at very early stages of pregnancy (Gropp and Winkin, 1981).

\section{SPONTANEOUS ABORTIONS}

Carr (1963) was the first to demonstrate the importance of chromosome abnormalities in abortions and there are now results available from many cytogenetic studies of spontaneous abortions. The surveys have been done in many different countries but the results, after standardization for gestational age, are remarkably similar. This uniformity suggests that a high rate of chromosome aberration is a very basic feature of human reproduction and one that is little influenced by geography or ethnicity.

The results of a number of abortion surveys are summarized in Table I (Jacobs and Hassold, 1987). As can be seen, approximately $50 \%$ of all abortions are chromosomally abnormal, the 4 main classes of abnormality being sex chromosome monosomy ( $9 \%$ ), trisomy (27\%), polyploidy $(10 \%)$ and structural rearrangements $(2 \%)$. Among the trisomics (table II), there is great variation in the frequency with which different chromosomes are represented. Trisomy 16 is by far the commonest class

Table I. Cylogenetic studies in spontaneous abortions.

\begin{tabular}{lcccccc}
\hline \multirow{2}{*}{$\begin{array}{l}\text { Total } \\
\text { karyotyped }\end{array}$} & \multicolumn{5}{c}{ Abnormal } & \multicolumn{1}{c}{$\begin{array}{l}\text { Total } \\
\text { abnormal }\end{array}$} \\
\cline { 2 - 5 } & $45, X$ & trisomic & polyploid & structural & other & \\
\hline no 7,182 & 615 & 1,923 & 709 & 147 & 50 & 3,444 \\
$\% \quad 100$ & 8.6 & 26.8 & 9.9 & 2.0 & 0.7 & 48.0 \\
\hline
\end{tabular}

\footnotetext{
a Total from 7 surveys of spontaneous abortions.
} 
Table II. Trisomics: frequency in different populations and probability of survival to birth.

\begin{tabular}{|c|c|c|c|c|}
\hline \multirow[t]{2}{*}{ Chromosome } & \multicolumn{3}{|c|}{ Population } & \multirow{2}{*}{$\begin{array}{l}\text { Probability } \\
\text { of survival } \\
\text { to birth a } \\
\text { (\%) }\end{array}$} \\
\hline & $\begin{array}{l}\text { spontaneous } \\
\text { abortions }\end{array}$ & stillbirths & livebirths & \\
\hline 1 & - & - & - & - \\
\hline 2 & 1.1 & - & - & 0 \\
\hline 3 & 0.3 & - & - & 0 \\
\hline 4 & 0.8 & - & - & 0 \\
\hline 5 & 0.1 & - & - & 0 \\
\hline 6 & 0.3 & - & - & 0 \\
\hline 7 & 0.9 & - & - & 0 \\
\hline 8 & 0.8 & - & - & 0 \\
\hline 9 & 0.7 & 0.1 & - & 0 \\
\hline 10 & 0.5 & - & - & 0 \\
\hline 11 & 0.1 & - & - & 0 \\
\hline 12 & 0.2 & - & - & 0 \\
\hline 13 & 1.1 & 0.3 & 0.005 & 2.8 \\
\hline 14 & 1.0 & - & - & 0 \\
\hline 15 & 1.7 & - & - & 0 \\
\hline 16 & 7.5 & - & - & 0 \\
\hline 17 & 0.1 & - & - & 0 \\
\hline 18 & 1.1 & 1.2 & 0.01 & 5.4 \\
\hline 19 & $<0.1$ & - & - & 0 \\
\hline 20 & 0.6 & - & - & 0 \\
\hline 21 & 2.3 & 1.1 & 0.12 & 22.1 \\
\hline 22 & 2.7 & 0.1 & - & 0 \\
\hline$X X Y$ & 0.2 & 0.4 & 0.05 & 55.3 \\
\hline$x x x$ & 0.1 & 0.3 & 0.05 & 70.0 \\
\hline$X Y Y$ & - & - & 0.05 & 100.0 \\
\hline Mosaic trisomy & 1.1 & 0.5 & 0.02 & 9.0 \\
\hline Double trisomy & 0.8 & - & - & 0 \\
\hline Total & 26.1 & 4.0 & 0.3 & 6 \\
\hline
\end{tabular}

a Assuming $15 \%$ spontaneous abortion and $1 \%$ stillbirth.

and accounts for over $30 \%$ of all additional chromosomes, while chromosomes 21 and 22, the next most frequent, account for a further $20 \%$ of all trisomies. At the other end of the spectrum is trisomy for chromosome 1 which has never been seen, and trisomies for chromosomes 5, 11, 12, 17 and 19 which are very rare. The frequency of trisomics for different chromosomes is clearly not simply related to size but must reflect both the frequency of their occurrence and their relative lethality when present in triplicate.

\section{STILLBIRTHS}

Less information is available on the chromosome constitution of stillbirths than of spontaneous abortion (table III) and, while 
Table III. Cytogenetic studies in stillbirths.

\begin{tabular}{cccccccc}
\hline & $\begin{array}{c}\text { Total } \\
\text { karyotyped }\end{array}$ & \multicolumn{5}{c}{ Abnormal } & Total \\
\cline { 3 - 6 } & & $45, X$ & trisomic & polyploid & structural & other & \\
abnormal \\
\hline no & 798 & 2 & 13 & 5 & 3 & 5 & 45 \\
$\%$ & 100 & 0.25 & 3.8 & 0.6 & 0.4 & 0.6 & 5.6 \\
\hline
\end{tabular}

a Total from 5 surveys of stillbirths.

the overall frequency of chromosome abnormalities is approximately $6 \%$, an order of magnitude lower than in spontaneous abortions, the rate among macerated fetuses $(10 \%)$ is much higher than the rate among non-macerated fetuses (3.5\%) (Jacobs and Hassold, 1987). As the success rate for culturing macerated tissue is low, the actual number of chromosome abnormalities in stillbirths is probably much higher than the $6 \%$ that are detected. Twothirds of the abnormalities in stillbirths are trisomies and the chromosomes involved are similar to those associated with livebirths, almost all having an additional chromosome $13,18,21$ or an $X$.

\section{LIVEBIRTHS}

A number of surveys of consecutive liveborn babies have established the frequency of chromosome abnormalities in this population to be $0.6 \%$ (table IV) (Hook and Hamerton, 1977), an order of magnitude less than stillbirths and two orders of magnitude less than spontaneous abortions. The type of abnormality is rather different from that associated with fetal death, with balanced structural rearrangements and additional sex chromosomes being the most frequent categories, and sex chromosome monosomies and autosomal trisom- ies, other than those for chromosome 21 , being relatively rare.

The great majority of newborn surveys was done on non-banded preparations and, therefore, while the frequencies of numerical abnormalities are accurate, the frequencies of structural rearrangements are underestimates. Recently, Hook and his colleagues (1989) have attempted to refine the frequencies of structural rearrangements in the newborn to allow for observations made on banded preparations. We have made a similar adjustment for balanced structural rearrangements based on material collected in the Wessex Regional Cytogenetics Unit. As can be seen from table V, Hook et al suggest, that while banding makes only a marginal difference in the frequency with which unbalanced structural rearrangments are observed, it makes a substantial difference in the frequency with which balanced structural rearrangements are observed. Hook et al, suggest that the frequency of structural rearrangements (excluding paracentric inversions) detected with moderate levels of banding is 3.4 per thousand, an increase of $79 \%$ on the 1.9 observed in the newborn surveys. We estimated the frequency to be 5.0 per thousand excluding paracentric inversions and 6.4 including paracentric inversions. Thus the observable frequency 
Table IV. Cytogenetic studies in the newborn.

\begin{tabular}{|c|c|c|c|c|c|c|c|c|c|}
\hline & \multirow{3}{*}{$\begin{array}{c}\text { Total } \\
\text { karyotype a }\end{array}$} & \multicolumn{6}{|c|}{ Abnormal } & \multirow{3}{*}{ other } & \multirow{3}{*}{$\begin{array}{c}\text { Total } \\
\text { abnormal }\end{array}$} \\
\hline & & \multicolumn{2}{|c|}{$45, x$} & \multicolumn{2}{|c|}{ trisomic } & \multicolumn{2}{|c|}{ structural $^{b}$} & & \\
\hline & & $45, X$ & mosaic & sex & autosome & $\begin{array}{c}\text { bal- } \\
\text { anced }\end{array}$ & $\begin{array}{l}\text { unbal- } \\
\text { anced }\end{array}$ & & \\
\hline \multicolumn{10}{|c|}{ Male } \\
\hline $\begin{array}{l}\text { no } \\
\%\end{array}$ & $\begin{array}{r}37779 \\
100\end{array}$ & - & $\begin{array}{c}1 \\
<0.01\end{array}$ & $\begin{array}{l}83 \\
0.22\end{array}$ & - & - & - & $\begin{array}{l}14 \\
0.04\end{array}$ & $\begin{array}{l}98 \\
0.26\end{array}$ \\
\hline \multicolumn{10}{|c|}{ Female } \\
\hline $\begin{array}{l}\text { no } \\
\%\end{array}$ & $\begin{array}{r}19173 \\
100\end{array}$ & $\begin{array}{l}2 \\
0.01\end{array}$ & $\begin{array}{l}5 \\
0.03\end{array}$ & $\begin{array}{l}22 \\
0.11\end{array}$ & - & - & - & - & $\begin{array}{l}29 \\
0.15\end{array}$ \\
\hline \multicolumn{10}{|l|}{ All } \\
\hline no & 56952 & - & - & - & $\begin{array}{l}81 \\
0.14\end{array}$ & $\begin{array}{l}110 \\
0.19\end{array}$ & $\begin{array}{l}34 \\
0.06\end{array}$ & $\begin{array}{c}1 \\
<0.01\end{array}$ & $\begin{array}{l}226 \\
0.40\end{array}$ \\
\hline
\end{tabular}

a Total from 6 surveys. ${ }^{b}$ Non-banded.

Table V. Rates of structural chromosome abnormalities per 1000 livebirths.

\begin{tabular}{lclc}
\hline Type & $\begin{array}{c}\text { Non-banded } \\
\text { rates }\end{array}$ & \multicolumn{2}{c}{ Adjusted banded rates } \\
\cline { 3 - 4 } & & Hook & Wessex \\
\hline $\begin{array}{l}\text { Unbalanced } \\
\text { rob trans }\end{array}$ marker ch & 0.07 & 0.07 & - \\
other & 0.30 & 0.30 & - \\
Total unbalanced & 0.23 & 0.35 & - \\
Balanced & 0.60 & 0.72 & - \\
rob trans & & & 0.91 \\
rec trans & 0.91 & 0.91 & 2.91 \\
peri inv & 0.90 & 1.85 & 1.20 \\
para inv & 0.14 & 0.62 & 1.37 \\
Total balanced & - & - & 6.39 \\
\hline
\end{tabular}

a Hook and Hamerton (1977); b Hook et al (1989). 
of structural rearrangements in the newborn using moderate levels of banding may well be approximately 6 per thousand and this estimate increases the rate of chromosome abnormality detectable in the newborn from $0.57 \%$ to approximately $1 \%$.

\section{ALL CLINICALLY RECOGNIZED PREGNANCIES}

In table VI are summarized the observations on chromosome abnormalities in spontaneous abortions, stillbirths and livebirths together with the probabilities of survival to term, under the conservative assumption that $15 \%$ of all clinically recognized pregnancies are lost prior to birth. It is evident that, with the exception of balanced structural rearrangements, survival to term is an exceptional event. Thus prenatal lethality is the rule for all polyploids, almost all trisomics and the vast majority of sex chromosome monosomics. In the latter category, fewer than 1 in $30045, X$ fetuses survive to term. When the trisomics are considered individually (table II) it can be seen that of the 3 autosomal trisomics that are compatible with livebirth, only 1 in 30 trisomic 13 conceptuses, 1 in 20 trisomic 18 conceptuses and 1 in 5 trisomic 21 conceptuses are born alive. Surprisingly enough, even among conceptuses with an additional $X$ chromosome, there is considerable selective prenatal loss; only $55 \%$ of $47, X X Y$ and $70 \%$ of $47, X X X$ individuals survive to term. In contrast, there is no evidence of any selective prenatal mortality of $47, X Y Y$ individuals. At the most conservative estimate, only $6 \%$ of abnormalities seen in clinically recognized pregnancies survive to term, the remaining $94 \%$ of observable chromosome abnormalities being associated with clinically recognized pregnancy losses. It is reasonable to postulate that a similar number of chromosome abnormalities are associated with early undetected pregnancy losses. These chromosome abnormalities must account

Table VI. Frequency and distribution of chromosome abnormalities in different populations ${ }^{\mathrm{a}}$.

\begin{tabular}{|c|c|c|c|c|c|c|c|}
\hline \multirow[t]{2}{*}{ Population } & \multicolumn{6}{|c|}{ Abnormality (\%) } & \multirow{2}{*}{$\begin{array}{l}\text { Total } \\
\text { abnormal }\end{array}$} \\
\hline & $45, X$ & trisomic & triploid & tetraploid & structural & other & \\
\hline $\begin{array}{l}\text { Spontaneous } \\
\text { abortions }\end{array}$ & 8.6 & 26.8 & 7.3 & 2.5 & 2.0 & 0.7 & 47.9 \\
\hline Stillbirths & 0.25 & 3.8 & 0.6 & - & 0.4 & 0.6 & 5.65 \\
\hline Livebirths & $<0.01$ & 0.30 & - & - & $0.25^{b}$ & 0.02 & 0.57 \\
\hline $\begin{array}{l}\text { All clinically } \\
\text { recognized } \\
\text { pregnancies a }\end{array}$ & 1.30 & 4.31 & 1.10 & 0.38 & 0.76 & 0.15 & 8.0 \\
\hline $\begin{array}{l}\text { Probability } \\
\text { of survival } \\
\text { to birth }(\%)\end{array}$ & 0.3 & 5.8 & 0 & 0 & 27 & 11.5 & 6 \\
\hline
\end{tabular}

\footnotetext{
assuming $15 \%$ spontaneous abortion $1 \%$ stillbirth. ${ }^{b}$ Uncorrected for banding.
} 
for the great majority of all human preembryonic, embryonic and fetal wastage. Because chromosome abnormalities play such a significant role in fetal wastage, it seems appropriate to examine the information currently available on their mechanisms of origin.

\section{ORIGIN OF NUMERICAL CHROMOSOME ABNORMALITIES}

Until recently, the parental origin of chromosome abnormalities could only be investigated by following the segregation of a chromosome heteromorphism or a gene from the parents to the chromosomally abnormal conceptus. This approach is limited because common chromosome heteromorphisms are found on only 10 of the 23 pairs of chromosomes, while suitable genes with a sufficiently high frequency of common alleles are rare, being effectively restricted to the genes of the HLA system, to the XGA blood groups or G6PD alleles in those races with a high frequency of polymorphism at this locus. Furthermore, while any genetic marker segregating in a Mendelian fashion can provide information on the parental origin of a missing or additional chromosome, only markers situated at, or extremely close to, the centromere can provide evidence on the specific cell division at which the error took place.

The recent recognition of restriction fragment length polymorphisms (RFLPs) has provided a battery of markers which segregate in a Mendelian fashion on every human chromosome and, therefore, it is now possible to ascertain the parental origin of virtually every chromosome abnormality. Furthermore, as RFLPs specific to the centromere of each individual chromosome are developed, it will be possible to establish the precise cell division at which the error occurred in the great majority of numerical chromosome abnormalities.

\section{THE ORIGIN OF SEX CHROMOSOME ABNORMALITIES}

\section{Sex chromosome monosomy}

Using a number of X-linked RFLPs, we have recently studied the parental origin of 66 apparently non-mosaic $45, X$ individuals (Hassold et al, 1990). Unfortunately, as the result of the error is not present, we can only infer the parental origin of the missing chromosome and it is not possible to investigate the cell division at which the error occurred. As can be seen from table VII, we found $80 \%$ to have a maternal $X$ and $20 \%$ a paternal $X$ irrespective of whether they were liveborn or spontaneously aborted. Thus, the error giving rise to the great majority of $45, X$ conceptuses occurs either during spermatogenesis or subsequent to fertilization with the selective involvement of a paternal sex chromosome.

\section{Klinefelter's syndrome}

We have investigated the origin of the additional sex chromosome in 111 males with a 47,XXY chromosome complement (Harvey et al, 1990). As the additional chromosome is present and there is an $X$ centromere-specific probe available, we were able to determine not only the parent who contributed the extra chromosome but also the cell division at which the error occurred. As can be seen from table VIII, 54 $(49 \%)$ were paternal in origin, having both an $X$ and $a Y$ chromosome from the father as a result of an error of the first paternal meiotic division. The remaining 57 (51\%) were maternal in origin. We successfully tested 39 of the 57 maternal cases with an $X$ chromosome centromere-specific probe, pBam X9, in order to determine the cell division at which the error occurred. In 28 
Table VII. Parental origin of the single $X$ chromosome in sex chromosome monosomy.

\begin{tabular}{lcc}
\hline Method of ascertainment & xpaternal & $x^{\text {matermal }}$ \\
\hline Spontaneous abortion & 8 & 28 \\
Therapeutic abortion & 0 & 4 \\
Liveborn-clinical referral & 5 & 17 \\
Newborn survey & 0 & 4 \\
Total & 13 & 53 \\
$\%$ & $(19.7)$ & $(80.3)$ \\
\hline
\end{tabular}

$(72 \%)$ of the cases, the error occurred at the first maternal meiotic division and in 11 $(28 \%)$ at the second maternal meiotic division. Furthermore, all 11 at which the centromere marker was homozygous were heterozygous at one or more distal loci, showing that the error occurred during the second meiotic division and not at an early post-zygotic division.

\section{The triple $X$ syndrome}

We have investigated the parental origin of $3147, X X X$ females (Hassold et al, 1989) and, as can be seen from table IX, found 2 $(6.5 \%)$ to have received their additional $X$ chromosome from their father, presumably as the result of non-disjunction at the sec- ond meiotic division of spermatogenesis, and $29(93.5 \%)$ to have an additional maternal $X$ chromosome. We successfully tested 21 of the 29 maternally derived $47, X X X$ females with a centromere probe and found $15(71 \%)$ to be the result of an error of the first maternal meiotic division and $6(29 \%)$ to be the result of a second maternal meiotic division error. Furthermore, all 6 cases in which the centromere was homozygous were shown to be heterozygous for one or more distal markers, thus excluding a post-zygotic mitotic error.

\section{THE ORIGIN OF AUTOSOMAL TRISOMY}

The only autosomal trisomy for which substantial numbers of patients have had the origin of their trisomy investigated using

Table VIII. Parental origin of the additional chromosome in $47, X X Y$ males.

\begin{tabular}{lcc}
\hline Method of ascertainment & Paternal & Maternal \\
\hline Amniocentesis for maternal age & 4 & 5 \\
Newborn survey & 27 & 34 \\
Subfertility & 4 & 5 \\
Clinical features & 19 & 13 \\
Total & 54 & 57 \\
$\%$ & $(49)$ & $(51)$ \\
\hline
\end{tabular}


Table IX. Parental origin of the additional chromosome in $47, X X X$ females.

\begin{tabular}{lcc}
\hline Method of ascertainment & Paternal & Maternal \\
\hline Therapeutic abortion & 0 & 5 \\
Newborn & 1 & 21 \\
Clinical referral & 1 & 3 \\
& 2 & 29 \\
Total & $(6.5)$ & $(93.5)$ \\
\hline
\end{tabular}

molecular probes is trisomy 21 (Takaesu et al, 1990). As can be seen from table $X$, in $27(18 \%)$ of the patients, the additional chromosome was paternal and in 125 $(82 \%)$ it was maternal. This figure agrees well with the estimates of $20 \%$ paternal and $80 \%$ maternal based on cytogenetic heteromorphisms (Takaesu et al, 1990). Comparatively few trisomies for other autosomes have been studied using molecular probes but all showed the majority to be maternal in origin (table X). When the observations on chromosome 21 are compared with those on the other autosomes, there appears to be a larger proportion of paternally derived cases for chromosome 21 than for the other autosomes, with the possible exception of chromosome 13. Clearly many more cases of trisomy must be studied before we know whether or not there are real differences in the proportion of paternally and maternally derived cases among different chromosomes.

\section{ESTIMATES OF THE NUMBER OF GAMETES WITH SPECIFIC CHROMOSOME ABNORMALITIES}

It is possible to predict the number of sperm and eggs with a specific chromosome abnormality from a knowledge of the frequency of the abnormality and the proportion that are attributable to a paternal or a maternal error. However, in so doing, a number of assumptions must be made. 1) All monosomies and trisomies result from errors at gametogenesis and no significant

Table X. Parental origin of autosomal trisomics using molecular probes.

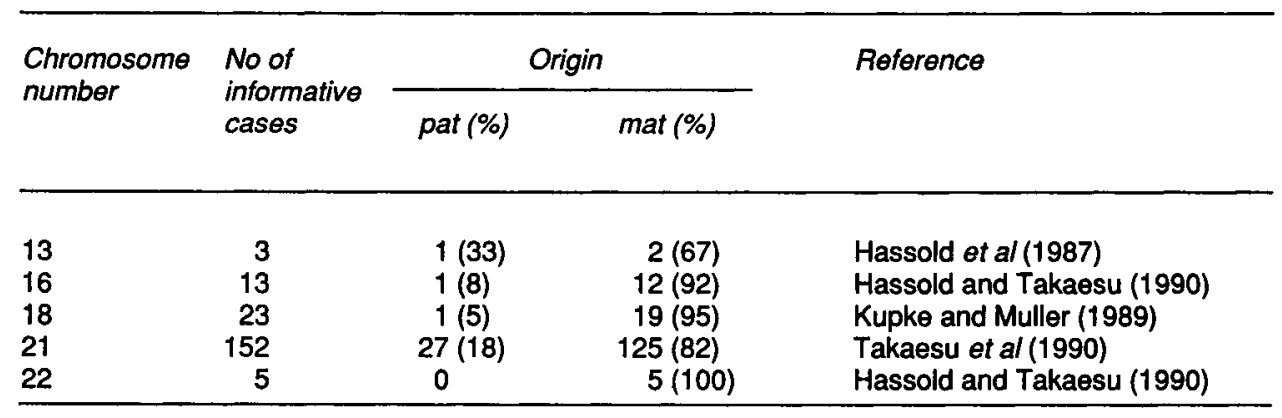


proportion arises post-fertilization. This seems a reasonable assumption for both sex and autosomal trisomies based on epidemiological information, the absence of a substantial proportion of mosaics and the failure to find evidence of somatic origin with molecular probes. However, it seems likely that most sex chromosome monosomies arise by a mechanism different from that causing trisomy. This suggestion is based on epidemiological evidence, the large number of sex chromosome monosomies compared to sex chromosome trisomies, and the very high proportion of mosaics, at least among the liveborn. The mechanism resulting in $45, X$ conceptuses may involve the production of abnormal gametes, eg, anaphase lag at meiosis, or it may occur after fertilization, eg, anaphase lag at an early cell division of the zygote. Therefore, the frequency of sex chromosomally abnormal gametes has been calculated in two ways, both including and excluding the data from $45, X$ conceptuses. 2) For every trisomic gamete there is a corresponding monosomic gamete. This seems a reasonable assumption based on the symmetry of the meiotic pro- cess and on evidence from the mouse (Gropp and Winkin, 1981). 3) There is no gametic selection prior to or at fertilization. This seems a reasonable assumption based on evidence from a very wide variety of organisms. 4) The calculated frequencies of trisomics among all clinically recognized pregnancies are an accurate reflection of their rate at conception. This seems an unlikely assumption because there is every reason to suppose that many autosomal trisomies are selected against prior to their giving rise to a clinically recognized pregnancy. However, it is impossible to obtain data on losses at the very early stages of pregnancy. Therefore the gametic frequencies calculated under assumption 4 must be serious underestimates for many chromosomes.

The frequency of 7 types of chromosome abnormalities among all clinically recognized pregnancies is given in table XI. These 7 abnormalities were selected either because the parental origin had been studied using molecular probes on more than 10 cases or because the parental origin could be deduced from the abnormality itself (XYY). The proportion of ab-

Table XI. Predicted frequency of chromosomally abnormal gametes.

\begin{tabular}{|c|c|c|c|c|c|}
\hline \multirow[t]{2}{*}{$\begin{array}{l}\text { Chromosome } \\
\text { abnormality }\end{array}$} & \multirow[t]{2}{*}{$\begin{array}{l}\text { Frequency among } \\
\text { all CRP a (\%) }\end{array}$} & \multicolumn{2}{|c|}{$\begin{array}{l}\text { Parental origin } \\
\text { of error (\%) }\end{array}$} & \multicolumn{2}{|c|}{$\begin{array}{c}\text { Abnormal gametes } \\
\text { (\%) }\end{array}$} \\
\hline & & pat & mat & sperm & eggs \\
\hline $45, x$ & 1.3 & 80 & 20 & 1.04 & 0.26 \\
\hline $47, X X Y$ & 0.08 & 49 & 51 & 0.04 & 0.04 \\
\hline $47, X X X$ & 0.05 & 6 & 94 & 0.003 & 0.047 \\
\hline $47, X Y Y$ & 0.04 & 100 & 0 & 0.04 & - \\
\hline $47,+16$ & 1.13 & 8 & 92 & 0.09 & 1.04 \\
\hline $47,+18$ & 0.18 & 5 & 95 & 0.009 & 0.171 \\
\hline $47,+21$ & 0.45 & 18 & 82 & 0.081 & 0.369 \\
\hline
\end{tabular}

a Clinically recognized pregnancies. 
Table XII. Predicted frequency of gametes with a sex chromosome abnormality.

\begin{tabular}{lll}
\hline Gamete & Sperm (\%) & Eggs (\%) \\
\hline $22,-$ & $0.083(1.123)^{a}$ & $0.087(0.347)^{a}$ \\
$24, X X$ & 0.003 & 0.087 \\
$24, X Y$ & 0.04 & - \\
$24, Y Y$ & 0.04 & - \\
\hline
\end{tabular}

a Including the $45, X$ conceptuses (see text).

normal gametes giving rise to these 7 abnormalities is also shown (table $\mathrm{XI}$ ). As can be seen, over $1.3 \%$ of sperm and $1.9 \%$ of eggs must have a chromosome abnormality leading to these 7 types of abnormal conceptuses.

When we consider individual autosomes, the frequency of nullisomic gametes must be at least the same as that for disomic gametes. This suggests that $0.18 \%$ of sperm and $2.08 \%$ of eggs have a missing or additional chromosome 16; $0.02 \%$ of sperm and $0.34 \%$ of eggs have a missing or additional chromosome 18 and $0.16 \%$ of sperm and $0.74 \%$ of eggs have a missing or additional chromosome 21 . The data for the sex chromosomes are shown in table XII. The figures have been calculated in two ways; firstly, on the assumption that the 3 types of sex chromosome trisomies are the results of errors of gametogenesis that produce disomic and nullisomic gametes with equal frequency and that the majority of $45, X$ conceptuses result from a post-fertilisation error and not an abnormal gamete and, secondly, on the assumption that all sex chromosome abnormalities are the result of errors of gametogenesis but that the nullisomic gametes that give rise to the majority of $45, X$ conceptuses have no disomic counterparts. On the first assumption $0.17 \%$ of sperm and $0.17 \%$ of eggs have a missing or additional sex chromosome, while on the second assumption $1.2 \%$ of sperm and $0.43 \%$ of eggs have a missing or additional sex chromosome.

A comparison of these predicted minimal frequencies of abnormal gametes with those actually observed for sperm, using the hamster oocyte test and in unfertilized and fertilized eggs, will be of great interest. Such comparisons should enable us to determine whether the large number of $45, X$ conceptions which have no paternal sex chromosome are the result of a gametic or a post-fertilization error and also enable us to estimate the number of undetected preimplantation and early post-implantation losses that are attributable to chromosomally abnormal gametes.

\section{ACKNOWLEDGMENTS}

This work was supported by the Wellcome Trust.

\section{REFERENCES}

Carr DH (1963) Chromosome studies in abortuses and stillborn infants. Lancet ii, 603

Gropp A, Winkin H (1981) Robertsonian translocations: cytology, meiosis, segregation patterns and biological consequences of hetero- 
zygosity. Symp Zool Soc London 47, 141181

Harvey J, Jacobs P, Hassold T, Pettay D (1990) The parental origin of $47, X X Y$ males. In: March of Dimes, Birth Defects Foundation, Birth Defocts, Original Articlo Series (Hammerton JL, Evans JA, eds)

Hassold TJ, Takeasu N (1989) Analysis of nondisjunction in human trisomic spontaneous abortions. In: Molecular and Cytogenetic Studies of Non-Disjunction (Hassold T, Epstein, eds) Alan R Liss, Inc, New York, 115134

Hassold T, Jacobs PA, Leppert M, Sheldon M (1987) Cytogenetic and molecular studies of trisomy 13. J Med Genet 24, 725-732

Hassold T, Arnovitz K, Jacobs PA, May K, Robinson D (1990) The parental origin of the missing or additional chromosomes in 45, $X$ and 47, XXX females. In: March of Dimes, Birth Defects Original Article Series (Hamerton JL, Evans JA, eds)

Hook EB, Hammerton $J L$ (1977) The frequency of chromosome abnormalities detected in consecutive newborn studies. In: Population
Cytogenetics. Academic Press, New York, 63-79

Hook EB, Healy N, Willey A (1989) How much difference does chromosome banding make? Ann Hum Genet 54, 237-242

Jacobs PA, Hassold TJ (1987) Chromosome abnormalities: comparative epidemiology in abortions and livebirths. In: Proc 7th int Congr Hum Genet Berlin, 1986 (Vogel F, Sperling K, eds) Springer-Verlag, Berlin, 233244

Kline J, Stein Z (1985) Very early pregnancy. In: Reproductive Toxicology, Raven Press, New York, 251-265

Kupke KG, Muller U (1989) Parental origin of the extra chromosome in trisomy 18. Am J Hum Genet 45, 599-606

Short RV (1979) When a conception fails to become a pregnancy. In: Maternal Recognition of Pregnancy, Exerpta Medica, Amsterdam, 377-387

Takaesu N, Jacobs PA, Cockwell A, Blackston RD, Freeman S, Nuccio J, Kurnit D, Uchida I, Hassold T (1989) Non-disjunction of chromosome 21. Am J Med Genet (in press) 